\title{
Rapid unpredicted changes in the stratification of marine lake Mogilnoe (Kildin Island, the Barents Sea) through the early 21 st century
}

\author{
Petr Strelkov'1,2, Igor Stogov' ${ }^{1}$ Elena Krasnova³, Ekaterina Movchan', Nataliya Polyakova',4, Sergei Goldin ${ }^{5}$,

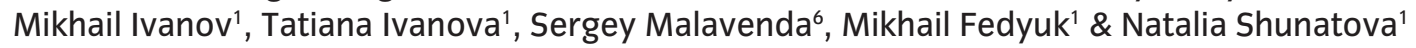 \\ ${ }^{1}$ Saint Petersburg State University, Saint Petersburg, Russia; \\ ${ }^{2}$ Laboratory of Monitoring and Conservation of Natural Arctic Ecosystems, Murmansk Arctic State University, Murmansk, Russia; \\ ${ }^{3}$ Nikolai Pertsov White Sea Biological Station, Lomonosov Moscow State University, Moscow, Russia; \\ ${ }^{4}$ A.N. Severtsov Institute of Ecology and Evolution, Moscow, Russia; \\ ${ }^{5}$ Russian State Hydrometeorological University, Saint Petersburg, Russia; \\ ${ }^{6}$ Murmansk State Technical University, Murmansk, Russia
}

\begin{abstract}
Lake Mogilnoe is a rare example of an anchialine lake (with subterranean connection to the ocean) in the Arctic, a refuge for landlocked populations of marine organisms. The lake has been the subject of intensive studies since the end of the 19th century. Here we demonstrate that between the 2003-07 and 2015-18 observation periods this permanently stratified lake experienced significant changes. The surface salinity increased and exceeded the tolerance limits of many freshwater organisms. The bottom anoxia expanded from onefifth to one-third of the lake volume. Such a turn in stratification affected both composition and distribution of biota: freshwater zooplanktonic species virtually disappeared, while benthic communities shifted to shallower depths. Although recent changes in the lake stratification are consistent with the longterm trend, their scale is much larger than has been observed during the past 120 years. It was earlier considered that the lake dynamics were mainly affected by human activity in the vicinity of the lake. However, lack of human activity around Mogilnoe during last decades persuades us to search for the natural causes of the recorded changes.
\end{abstract}

To access the supplementary material, please visit the article landing page

\section{Keywords}

Arctic anchialine lake; water stratification; zoobenthos; zooplankton; inter-annual changes; conservation

\section{Correspondence}

Petr Strelkov, Saint Petersburg State University, Universitetskaya Emb., 7-9, Saint Petersburg 199034, Russia. E-mail: p_strelkov@yahoo.com

\section{Abbreviations}

IUCN: International Union for Conservation of Nature

PSU: practical salinity unit

\section{Introduction}

Permanently stratified saline or brackish water bodies are not rare along the coasts of Fennoscandia, which are indented by fjords and inlets and are undergoing postglacial rebound (Strøm 1936; Lindholm 1996; Ström \& Klaveness 2003; Krasnova et al. 2015). Such water bodies with surface connection with the sea are traditionally categorized as landlocked waters (Strøm 1936). In the course of progressive isolation from the sea, the surface waters of landlocked basins are freshened, water density stratification is strengthened and bottom-water anoxia is expanded (Strøm 1936; Krasnova et al. 2015). In the short term, the dynamics of landlocked waters are governed by the eutrophication patterns controlling the extent of anoxia as well as meteorological and hydrological events that affect the water density stratification (Fallesen et al. 2000; Ström \& Klaveness 2003; Pakhomova et al. 2014).

Lake Mogilnoe on Kildin Island in the Barents Sea (Fig. la-c), is a small marine meromictic lake, 16-m deep, with a total surface area of 17 ha. Unlike landlocked waters, Mogilnoe communicates with the sea not at the surface but subterraneanly by filtering water through loose rocks. For such systems with subsurface connection with the sea, the term "anchialine" was coined by Holthuis (1973). The lake is traditionally described as a freshwater-marine three-layered basin: the upper layer is characterized as "fresh" (though, formally, it is 

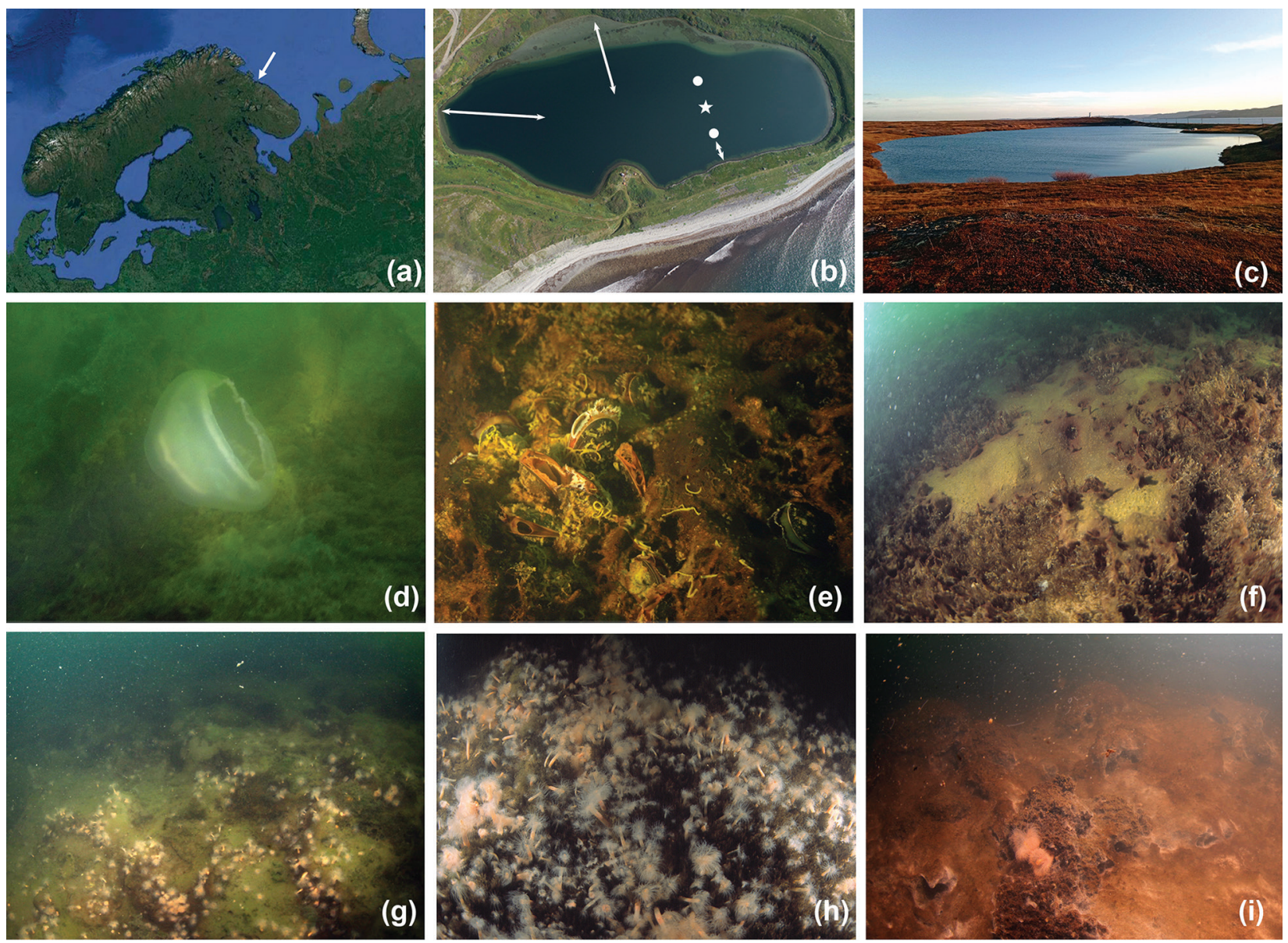

Fig. 1 Lake Mogilnoe and its inhabitants. (a) Map of northern Europe; arrow indicates location of Kildin Island. (b) Lake Mogilnoe from a bird's-eye view (photograph by A.A. Sazonov). The star indicates the point of hydrological and plankton sampling. The dots indicate sites of additional plankton sampling. Benthic transects are indicated by arrows. (c) Close up view of Lake Mogilnoe, with the strait between Kildin Island and Kola Peninsula in the background. The photograph was taken on 22 October 2018. (d) Moon jelly Aurelia aurita. The photograph was taken on 3 August 2016 at 3-4-m depth. (e) Clump of Mytilus edulis, 3.5-m depth. (f-i) Changes in benthic communities along the southern slope of the lake over 11 years at (f, g) 3-m depth and (h, i) 7-m depth. Photographs (f) and (g) were taken in 2007, and (h) and (i) in 2018. See the supplementary material for more photographs illustrating temporal changes in the lake.

oligohaline, with 1-5 PSU salinity), the middle layer is saline (with 5-30 PSU salinity and prominent halocline) and oxygenated, and the bottom layer is saline and sulfidic (Derjugin 1925). Mogilnoe is a rare example of a polar anchialine lake. Its closest counterparts are the tropical "jellyfish lakes" of Palau, Vietnam and Indonesia that communicate with the sea through underground tunnels and fissures in the limestone (Dawson et al. 2009; Becking et al. 2011; Dawson 2015). In addition to similarity in the mode of water exchange with the sea, Lake Mogilnoe also shares some biological features with tropical lakes, such as isolation, endemism and the presence of large flocks of sea anemones, scyphomedusae and suberitid sponges (Strelkov et al. 2014). On the other hand, the presence of the resident population of
Atlantic cod (Gadus morhua) equates Mogilnoe to Arctic "cod lakes" (landlocked waters) of Canada, Greenland, Norway and Russia (Hardie et al. 2008).

Mogilnoe is the "oldest" marine lake in the scientific record, having been surveyed since the 1890s. The lake was traditionally considered very stable temporally (Derjugin 1925). Nevertheless, during the observation period (intensive studies of the lake were performed during 1894-1921, 1968-69 and 2003-07), the vertical stratification of the lake's waters and its biodiversity changed. From the 1920s to the 1960s, the bottom anoxia expanded by about $2 \mathrm{~m}$ upwards; in addition, the upper "freshwater" layer decreased by $2 \mathrm{~m}$ between the 1960s and 2000s. Macrofaunal diversity decreased by nearly $50 \%$ during the 20 th century, down to three 
species of fishes, 14 species of macrozooplankton and mesozooplankton and 17 species of macrozoobenthos (Strelkov et al. 2014). These changes were suggested to be a long-term trend and primarily related to anthropogenic impact (Gurevich et al. 1975; Strelkov et al. 2014). The range of more short-term (decadal scale) variation in the lake has not been evaluated so far. Here we present data on vertical stratification of the lake by temperature, salinity and oxygen content, the diversity of zooplankton and the vertical distribution of benthos in the period 2015-18 in comparison with the corresponding data from the period 2003-07. For the first time, we carefully evaluate the decadal-scale dynamics of Lake Mogilnoe, making use of previous studies as well as recent research on the lake, which provides a unique time series for an Arctic meromictic lake.

\section{Materials and methods}

The lake was examined on 18-25 July 2015, 2-8 August 2016, 20-28 July and 20-24 August 2018. We generally followed the sampling scheme of our previous study (Strelkov et al. 2014). Data from that paper (original data from 2003 to 2007, review of published historic data) along with unpublished underwater photographs of 2007 were used for comparison.

Temperature, salinity and oxygen content (oxygen content in 2015 and 2018 only) were measured at the station in the deepest part of the lake $\left(69^{\circ} 19.09^{\prime} \mathrm{N}\right.$, $\left.34^{\circ} 21.01^{\prime} \mathrm{E}\right)$ with an increment of $1 \mathrm{~m}$ using WTW multi 340i meter equipped with measuring cell TetraCon ${ }^{\circledR} 325$ and thermo-oxygen meter equipped with optic electrodes (Expert 009, Econix-Expert Ltd.). The position of chemocline was also determined by the colour (the border of anoxic layer is coloured red because of sulphur bacteria) and the odour (hydrogen sulphide smells like rotten eggs) of water. Zooplankton was sampled each time at three stations (the station of hydrological sampling and two additional stations: $69^{\circ} 19.07^{\prime} \mathrm{N}, 34^{\circ} 21.03^{\prime} \mathrm{E}$; $69^{\circ} 19.164^{\prime} \mathrm{N}, 34^{\circ} 21.052^{\prime} \mathrm{E}$; Fig. 1b) with the Juday net (mesh size $0.12 \mathrm{~mm}$; mouth diameter $26 \mathrm{~cm}$ ), hauled vertically through the anoxic zone.

In 2015, divers collected benthos along three vertical transects in different parts of the lake (Fig. lb, transects corresponds to transects B, C and D in Strelkov et al. 2014 ) at $0.25-0.5-\mathrm{m}, 3.5-4.5-\mathrm{m}$ and $6-7-\mathrm{m}$ depths, with four samples for each depth interval: one cogged grab sample (sampling area $0.04 \mathrm{~m}^{2}$ at $0.3 \mathrm{~m}$ or $0.025 \mathrm{~m}^{2}$ at a greater depth) and three core samples (sampling area $0.005 \mathrm{~m}^{2}$ ). Divers also visually mapped and photographed bottom communities along the southern slope of the lake, where the seawater seeps through the dam and zoobenthos demonstrate a distinct vertical zonality in distribution. Special attention was paid to "megabenthic" species previously found in the lake: blue mussel (Mytilus edulis), the sabellid polychaete Pseudopotamilla reniformis, the sea anemone Metridium senile and the red algae Coccotylus truncates (Pallas). These species formed dense but scattered settlements along the southern slope, mostly away from stations of quantitative sampling (Strelkov et al. 2014).

Animals from quantitative samples were usually identified with the level of species (except for oligochaetes and chironomids), counted and wet-weighted with accuracy to $1 \mathrm{mg}$.

\section{Results and discussion}

Depth profiles of salinity, temperature and oxygen, lists of recorded species and abundance of dominant species from the period 2015-18 are presented in the Supplementary Material, together with comparable data from earlier surveys. The general characteristics of the water-column stratification in the period 2015-18 are as follows: The highest concentration of oxygen was registered at 3-5-m depth. The water was almost oxygen-free below 7-m depth. The red water layer was at the $7-8-m$ depth. The deeper water samples smelled of rotten eggs. Salinity at the surface (0-2-m depth) was 5-8 PSU and below $7 \mathrm{~m}$, it reached 26-31 PSU. Halocline (at depth of 2-7 m) separated the surface and bottom waters. The temperature generally decreased with depth down to $8^{\circ} \mathrm{C}$; maximal temperature was observed either at the surface (in July 2018) or at depths of 3-7 m (other surveys) (Supplementary Table S1). Comparing recent data with that of 2003-07, we revealed a considerable change in the depth of the sulfidic layer and in the salinity of surface waters. In the period 2003-07, the salinity at the surface was 3-4 PSU, while at a depth of $5 \mathrm{~m}$ it was 15-20 PSU. In the period 2015-18 at similar depths, the values were 5-8 PSU and 22-25 PSU, respectively (Fig. 2a). The red water layer was 2-m deeper in 2003-07 (Fig. 2b). In the period from 2007 to 2015, the anoxic zone expanded from one-fifth up to one-third of the lake's volume (volume recalculated from bathymetric data in Gurevich 1975a). At first glance, recent changes are consistent with the long-term trend. For example, in 1921, the hydrogen sulphide was registered at 12-m depth and salinity at 5-m depth was 4 PSU (Derjugin 1925). However, changes during the last decade are on a larger scale than during the preceding 120 years of observation (Fig. 2b; Supplementary Table S1).

In total, 13 forms of zooplankton were recorded in the period 2015-18 (Supplementary Table S2). The species 

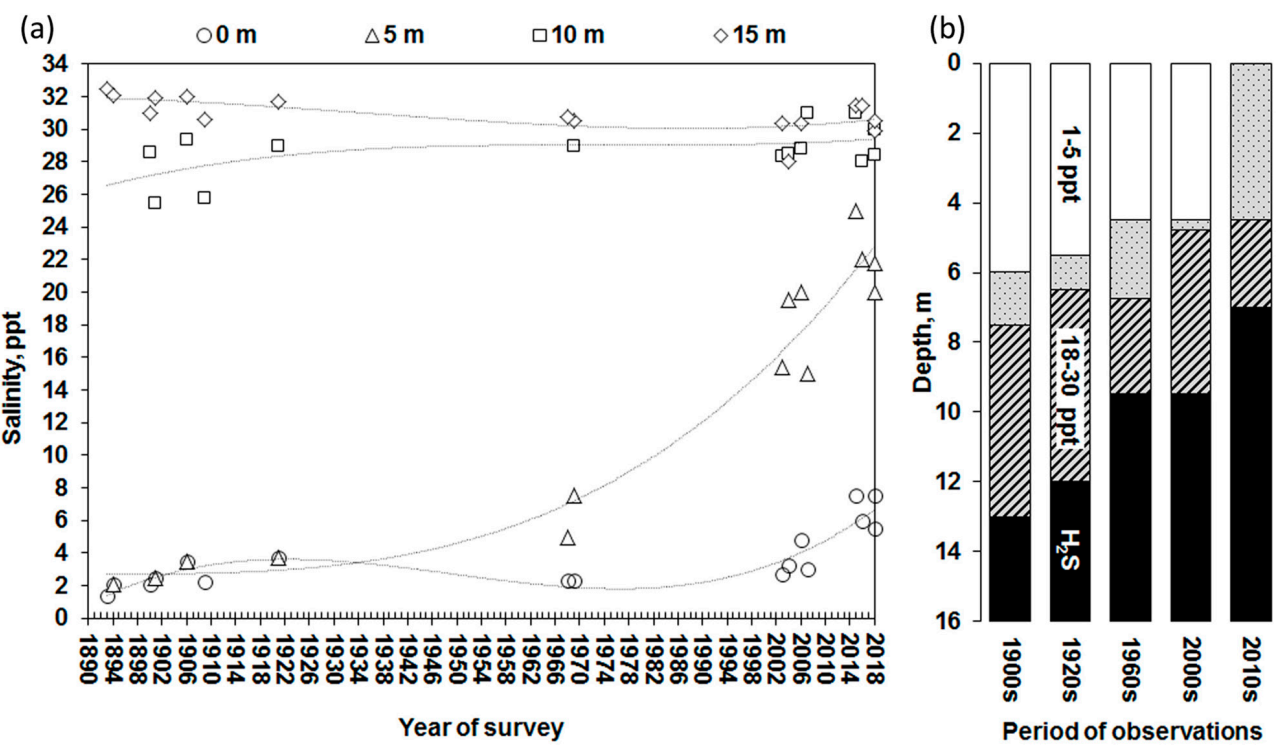

Fig. 2 Temporal changes in the stratification of Lake Mogilnoe. (a) Salinity (given as parts per thousand [ppt]) changes over decades at different depths. All observations were made in July or August. Each point in the plot averages all measurements from a particular survey year. Each time series is approximated by a cubic polynomial match. (b) Diagrammatic representation of stratification in different decades.

list includes common taxa of the lake (except for Aurelia aurita) and is remarkable for the lack of freshwater species that were once common in the lake (Derjugin 1925; Fomin 1975; Supplementary Table S2). In terms of abundance, zooplankton was dominated by four forms-larvae of spionid polychaetes, copepod Pseudocalanus acuspes, cladoceran Pleopis polyphemoides and rotatorian Synchaeta sp.-which together comprise more than $95 \%$ of any sample abundance. The list of dominant forms in 2003-07 included spionid larvae, P. acuspes, P. polyphemoides and another rotifer, Keratella quadrata (Strelkov et al. 2014; Supplementary Fig. S1).

The finding of the moon jelly A. aurita (Fig. ld) in 2015 was quite unexpected. A single previous finding of this species (one specimen) dates to 1967 (Fomin 1975). In 2016, we encountered two aurelias (umbrella diameters of 15 and $39 \mathrm{~cm}$ ). However, another scyphozoan jellyfish-Cyanea capillata-was remarkably numerous in Lake Mogilnoe during recent and preceding surveys. It is worth nothing that Aurelia spp. are very characteristic for marine lakes worldwide (Dawson \& Jacobs 2001; Purba et al. 2018).

In total, only 20 taxa of zoobenthos were recorded in 2015 (Supplementary Table S3). We suggest that the observed reduction in the species list, compared to the 24 taxa observed in 2003-07 (Supplementary Table S3), may be partly explained by a relatively poor sampling effort in 2015 (but see also the Pseudopotamilla case below). We recorded two new species for the lake: the brittle star Ophiura robusta and the amphipod Gammarus locusta. Most probably, these species have recently arrived from the sea, as well as A. aurita (see more discussion on adventive species in the lake in Strelkov et al. 2014). It is interesting that ophioplutei were recorded in the lake only once, in 1900 (Derjugin 1925).

Visual observations detected a general upward shift in the vertical distribution of benthic organisms along the southern slope of the lake since the early 2000 s. In 2003-07, the benthos at 5-7-m depth was dominated by the sea anemone $M$. senile and red algae $C$. truncates and Polysiphonia stricta (Mertens ex Dillwyn), while at 7-9-m depth, it was dominated by spionids and tubificids (Annelida) and the ascidian Molgula citrina; in 2015, these communities were shifted to 3-5 and 5-7-m depths, respectively (Fig. If-i). Finally, we found several dense clusters of the mussel M. edulis located at 1-3-m depth (Fig. 1e). First detected in 2014 in the lake, mussels were rare and hardly noticeable before: they hid in the loose sediment at 5-m depth. The single dense cluster of the large sabellid polychaete Pseudopotamilla reniformis has disappeared that previously occurred at 6-7-m depth (see Strelkov et al. 2014 and Supplementary Fig. S2). Most likely, the lake has lost one of its most noticeable inhabitants. The visual observations of changes in the vertical distribution of zoobenthos along the southern slope are well 
supported by photographs taken at fixed coordinates (Supplementary Figs. S2-S4).

Along the transects, the list of dominant zoobenthic species was similar to that from the period 2003-07: the bivalve Macoma balthica (accepted now in the World Register of Marine Species as Limecola balthica), the polychaetes Polydora ciliata, Fabriciola balthica and Naineris quadricuspida, the amphipod Gammarus duebeni, the sea squirt M. citrina, oligochaetes and chironomids. However, their distribution and abundance in 2015 was different (Supplementary Fig. S5). The horizon of 8.5-9.5-m depth fell into the anoxic zone and therefore lacked any zoobenthic organisms. In both structure and abundance, the zoobenthic assemblage at 6-7-m depth in 2015 (dominated by $P$. ciliata and oligochaetes) is similar to that of 8.5-9.5-m depth in 2003-07 rather than that at 6-7 m (where M. citrina, F. baltica and N. quadricuspida were also additional dominant forms). Changes in the composition of species at shallow horizons were less noticeable.

Changes in the biota of the lake are obviously related to changes in its stratification. Owing to expansion of the bottom anoxia, conditions at depths below $7 \mathrm{~m}$ appear to be intolerable for aerobic organisms anymore. The decreased living space for marine species at depths is partly compensated for by increased salinity at shallows. The absence of many freshwater zooplankton species listed by Derjugin (1925) was already recorded in 2003-07 (Strelkov et al. 2014). In 2018, the surface salinity during the summer approached values considered as tolerance limits of freshwater organisms (5-8 PSU; Hlebovič 1974). However, we must remember that stratification of the lake changes seasonally (Derjugin 1925) and the question concerning its stratification and plankton composition during the period of spring freshening is still open.

Changes in stratification of Lake Mogilnoe during the last decade are at odds with earlier hypotheses about factors affecting its dynamics. Some authors (Stroganov et al. 2015) still adhere to the traditional paradigm about temporal invariability of the lake's ecosystem. This paradigm, dating back to Derjugin (1925), does not conform to the facts. The small decrease in the near-bottom salinity between the 1920s and the 1960s (Fig. 2a) was interpreted as a signature of progressive freshening of the lake-the pattern postulated for landlocked waters in the long-term period (Gurevich \& Shirokolobov 1975). It has turned out that the general trend in the change in salinity is the opposite: through recent decades, the salinity of the upper layer has been steadily increasing (Strelkov et al. 2014, this survey). It was suggested that the anoxia ascending in the lake would be limited by the depth level of water seeping from the sea (Strelkov et al.
2014). Nevertheless, nowadays the border of anoxic layer $(8 \mathrm{~m})$ intersects with the filtration horizon, which was estimated to be 5-8 $\mathrm{m}$ in the 1960s (Gurevich 1975a). Changes in the depth of anoxic layer and in the surface salinity through the 20th century were considered as unrelated because they had happened during different decades (Strelkov et al. 2014). However, at the beginning of the 21 st century, the change in salinity and in the depth of anoxia co-occurred (as shown in a recent study), which could indicate a common cause. The main factor affecting the lake's dynamics—-specifically the expansion of the anoxic layer-was attributed to organic pollution from the settlement situated close to the lake (Gurevich 1975b), while the thinning of the "freshwater" layer was chalked up to a reduction of the freshwater input into the lake due to road-building across the lake's catchment area (Strelkov et al. 2014). The lack of human activity around Lake Mogilnoe since the early 2000s (Strelkov et al. 2014; our observations) persuades us to consider the possible natural causes of the observed changes.

Landlocked waters are prone to extreme anoxic events, when the bottom anoxia expands into surface waters. The strong influx of high-density marine water because of storms and high tides or lack of wind combined with high biological production can cause anoxic events (Fallesen et al. 2000; Ström \& Klaveness 2003). No such anoxic events have been recorded in Lake Mogilnoe and we are sceptical that a lake communicating with the sea at depths of 5-8 $\mathrm{m}$ is very sensitive to extreme weather conditions. In any case, after anoxic events, stratification of landlocked waters is restored in a few months (Fallesen et al. 2000; Pakhomova et al. 2014), while the recent stratification pattern has remained in the lake for last four years. Increasing salinity in the lake indicates that either the input of the marine water has increased or the freshwater has decreased (in the 1960s, the daily average influx of freshwater and seawater into the lake was estimated as 400 and $45 \mathrm{~m}^{3}$, respectively [Gurevich 1975c]). The latter is most probably true. The single creek flowing into the lake (water discharge in summer 2012: $10.8 \mathrm{~m}^{3} \mathrm{~h}^{-1}$ [Stroganov et al. 2015]) has been completely dry during our expeditions since 2016 (Supplementary Fig. S6). An expansion of anoxic water layer could be provoked by an increase in surface salinity and corresponding weakening of water density gradient. The desiccation of the creek may be due to the high average annual temperatures of the air and seawater observed in the Barents Sea region over last two decades associated with the decadal temperature fluctuations of the Arctic Oscillation (water temperature data at the Kola section of the Barents Sea for 1951-2017 [http://www/pinro.ru/n22/labs/labhidro; Marshall et al. 2016]). Our other hypothesis explaining 
anoxic layer expansion concerns changes in the regime of water filtration between the lake and the sea: either the depth of the filtration horizon was estimated inaccurately in the 1960s or it has shifted upwards since then. To verify these hypotheses, reassessments of the hydrological balance of the lake and the regime of water filtration through the dam, as well as critical analyses of the hydrologic data from the 1960s, are needed.

\section{Conclusions}

Recent changes recorded in Lake Mogilnoe are negative in the sense that the lake is losing its unique features that have earned it special conservation status. The lake is protected by Russian law and has the IUCN status as a Natural Monument or Feature as a unique freshwater-marine lake where marine and freshwater organisms co-occur (http://oopt.aari.ru). In its present state, Lake Mogilnoe can hardly be characterized as freshwatermarine; it is now brackish-marine. Freshwater species are no longer a significant part of its biodiversity. The fate of this lake's entire ecosystem under such dynamic changes is a matter of concern. If the amount of scientific knowledge about the water basin is determined by the number of published pages per cubic metre of water, Lake Mogilnoe would be the most studied marine lake in the world. However, this heap of knowledge did not help to predict alterations in the lake in the recent years. The single studied representative of its category of anchialine lakes in the Arctic, Lake Mogilnoe still remains incomprehensible and therefore unpredictable for researches.

\section{Acknowledgements}

The authors are grateful to all members of the 2015 , 2016 and 2018 expeditions for their help in the field. The Centre for Molecular and Cell Technologies of St. Petersburg State University is acknowledged for help with the taxonomic identification of invertebrates.

\section{Disclosure statement}

The authors report no potential conflict of interest.

\section{Funding}

This study was supported by the Russian Foundation for Basic Research (project nos. 16-04-00723-a and 19-0500377-a) and Russian Geographical Society (project No. 254 13-218-P).

\section{References}

Becking L.B., Renema W., Santodomingo N.K., Hoeksema B.W., Tuti Y. \& de Voogd N.J. 2011. Recently discovered landlocked basins in Indonesia reveal great habitat diversity in anchialine systems. Hydrobiologia 677, 89-105, doi: 10.1007/s10750-011-0742-0.

Dawson M.N. 2015. Island and island-like marine environments. Global Ecology and Biogeography 25, 831-846, doi: $10.1111 /$ geb.12314.

Dawson M.N. \& Jacobs D.K. 2001. Molecular evidence for cryptic species of Aurelia aurita (Cnidaria, Scyphozoa). The Biological Bulletin 200, 92-96, doi: 10.2307/1543089.

Dawson M.N., Martin L.E., Bell L.J. \& Patris S. 2009. Marine lakes. In R. Gillespie \& D.A. Clague (eds.): Encyclopedia of islands. Pp. 603-607. Berkeley, CA: University of California Press.

Derjugin K.M. 1925. Reliktovoe ozero Mogil'noe (os. Kil'din v Barencevom more). (Relict Lake Mogilnoe [Kildin Island in the Barents Sea].) Leningrad: Nauka.

Fallesen G., Andersen F. \& Larsen B. 2000. Life, death and revival of the hypertrophic Mariager Fjord, Denmark. Journal of Marine Systems 25, 313-321, doi: 10.1016/ S0924-7963(00)00024-5.

Fomin O.K. 1975. Zooplankton. In V.I. Gurevich \& R.Y. Zeeb (eds.): Reliktovoe ozero Mogil'noe. (Relict Lake Mogilnoe.) Pp. 209-219. Leningrad: Nauka.

Gurevich V.I. 1975a. Rel'ef, batimetrija, morphometrija. (Relief, bathymetry, morphometry.) In V.I. Gurevich \& R.Y. Zeeb (eds.): Reliktovoe ozero Mogil'noe. (Relict Lake Mogilnoe.) Pp. 18-21. Leningrad: Nauka.

Gurevich V.I. 1975b. Okhrana oz. Mogil'nogo. (Protection of the lake Mogilnoe.) In V.I. Gurevich \& R.Y. Zeeb (eds.): Reliktovoe ozero Mogil'noe. (Relict Lake Mogilnoe.) Pp. 277-278. Leningrad: Nauka.

Gurevich V.I. 1975c. Gidrodinamika. (Hydrodynamics.) In V.I. Gurevich \& R.Y. Zeeb (eds.): Reliktovoe ozero Mogil'noe. (Relict Lake Mogilnoe.) Pp. 22-33. Leningrad: Nauka.

Gurevich V.I. \& Shirokolobov V.N. 1975. Temperatura. Solenost' i plotnost'. (Temperature. Salinity and density.) In V.I. Gurevich \& R.Y. Zeeb (eds.): Reliktovoe ozero Mogil'noe. (Relict Lake Mogilnoe.) Pp. 34-45. Leningrad: Nauka.

Gurevich V.I., Shirokolobov V.N. \& Pavlova L.G. 1975. Optičeskie svojstva. (Optical characteristics.) In V.I. Gurevich \& R.Y. Zeeb (eds.): Reliktovoe ozero Mogil'noe. (Relict Lake Mogilnoe.) Pp. 45-48. Leningrad: Nauka.

Hardie D.C., Renaud C.B., Ponomarenko V.P., Mukhina N.V., Yaragina N.A., Skjæraasen J.E. \& Hutchings J.A. 2008. The isolation of Atlantic cod, Gadus morhua (Gadiformes), populations in northern meromictic lakes-a recurrent Arctic phenomenon. Journal of Ichthyology 48, 230-240, doi: 10.1134/S0032945208030053.

Hlebovič [Khlebovich] V.V. 1974. Kritičeskaya solenost' biologičeskih processov. (Critical salinity of biological processes.) Leningrad: Nauka.

Holthuis L. B. 1973. Caridean shrimps found in land-locked saltwater pools at four Indo-West Pacific localities (Sinai Peninsula, Funafuti Atoll, Maui and Hawaii islands), with 
the description of one new genus and four new species. Zoologische Verhandelingen 128, 1-48.

Krasnova E., Voronov D., Frolova N., Pantyulin A. \& Samsonov T. 2015. Salt lakes separated from the White Sea. EARSeL eproceedings 14 (S1), 8-22, doi: 10.12760/02-2015-1-02.

Lindholm T. 1996. Periodic anoxia in an emerging coastline lake basin in SW Finland. Hydrobiologia 325, 223-230, doi: 10.1007/BF00014988.

Marshall G.J., Vignols R.M. \& Rees W.G. 2016. Climate change in the Kola Peninsula, Arctic Russia, during the last 50 years from meteorological observations. Journal of Climate 29, 6823-6840, doi: 10.1175/JCLI-D-16-0179.1.

Pakhomova S., Braaten H.F., Yakushev E. \& Skei J. 2014. Biogeochemical consequences of an oxygenated intrusion into an anoxic fjord. Geochemical Transactions 15(1), article no. 5, doi: 10.1186/1467-4866-15-5.

Purba G.Y., Haryono E., Sunarto S., Manan J., Rumenta L., Purwanto P. \& Becking L.E. 2018. Jellyfish lakes at Misool Islands, Raja Ampat, West Papua, Indonesia. Biodiversitas 19, 172-182, doi: 10.13057/biodiv/d190124.
Strelkov P., Shunatova N., Fokin M., Usov N., Fedyuk M., Malavenda S., Lubina O., Poloskin A. \& Korsun S. 2014. Marine Lake Mogilnoe (Kildin Island, the Barents Sea): one hundred years of solitude. Polar Biology 37, 297-310, doi: 10.1007/s00300-013-1431-4.

Stroganov A.N., Kriksunov E.A., Zuykova N.V., Mukhina N.V., Burmensky V.A., Semenova A.V. \& Shadrin A.M. 2015. The biological features of the Kildin cod, Gadus morhua kildinensis Derjugin, 1920 (Gadidae). Russian Journal of Marine Biology 41, 424-431, doi: 10.1134/S1063 074015060140.

Strøm K.M. 1936. Land-locked waters: hydrography and bottom deposits in badly-ventilated Norwegian fjords, with remarks upon sedimentation under anaërobic conditions. Det Norske Videnskaps-Akademi i Oslo I. Matematisk-Naturvidenskapelig Klasse 7. Oslo: Dybwad.

Ström T.E. \& Klaveness D. 2003. Hunnebotn: a seawater basin transformed by natural and anthropogenic processes. Estuarine, Coastal and Shelf Science 56, 1177-1185, doi: 10.1016/S0272-7714(02)00329-3. 